\title{
aa-hubs as an example of the utility of hub categorization in signaling research
}

\section{Lasse Staby}

Katrine Bugge

Rasmus Greve Falbe-Hansen

Edoardo Salladini

Karen Skriver

Birthe B. Kragelund

\section{Video Byte}

Keywords: Cell Communication and Signaling, interactome, intrinsically disordered protein, IDP, NCBD, PAH, RST, HHD, signaling, TAFH, hub proteins, aa-hubs, harmonin, review, comparative structural biology, signaling networks

Posted Date: February 25th, 2021

DOI: https://doi.org/10.21203/rs.3.rs-276039/v1

License: (c) (i) This work is licensed under a Creative Commons Attribution 4.0 International License. Read Full License 


\section{Abstract}

The fidelity of cellular signaling is largely dependent upon "hubs" of protein-protein interaction that integrate signals across large intersecting signaling webs. Hub proteins tend to have a high degree of intrinsic disorder, which allows them to interact with an array of differently structured proteins. However, in some cases the hub is structured and interacts with disordered ligands instead. One example is a recently described group of folded hubs, the aa-hubs, which are connected by a shared structural foundation. The aa-hubs are small a-helical domains found in large modular proteins that interact with disordered ligands such as transcription factors. A recent commentary suggests that the harmoninhomology-domain (HHD) belongs to the aa-hub group based on structural analysis. The inclusion of HHD adds several functions to the group, such as telomere regulation and neurovascular integrity. Connecting the aa-hubs as a group allows for greater insight not achievable through single hub analysis. Including HHD as an aa-hub uncovers new features of the group as a whole and highlights how discoveries about one member can aid in the discovery in others. 